\title{
TRANSPARANSI DAN PELAPORAN KEUANGAN LEMBAGA ZAKAT
}

\author{
Nur Hisamuddin \\ Universitas Negeri Jember (UNEJ) \\ e-mail: hi5am@yahoo.com
}

\begin{abstract}
BAZNAS has now transformed into a large and influential zakah institution in the life of Indonesian society due to the power of the Law that shelter it. This is an institution awaited by Muslims in general. This institution is the Shariah institution authorized entitled to receive and distribution of zakat, infaq and alms. Therefore this institution should be established by each region throughout Indonesia both at provincial and district levels. Therefore, transparency becomes crucial because of the many parties who are interested in zakah institutions. Transparency can be done by presenting reasonable financial statements. The organizers of zakat institutions should be obliged to understand the preparation of financial statements. This is in some areas are still frequent inequality and lack of understanding of the basics in the preparation of zakah institutional financial statements.
\end{abstract}

Keywords: Zakah Institution, Transparency and Financial Report 


\section{Pendahuluhan}

Zakat, infaq dan sedekah merupakan salah satu bentuk kepedulian sosial. Zakat, infaq, dan sedekah tersebut merupakan salah satu wujud terlaksanannya ekonomi manusiawi, yakni ekonomi yang mempertimbangkan keseimbangan manusia dengan lingkungan sekitarnya. Kekayaan tidak hanya berputar pada golongan-golongan tertentu saja, tetapi harus melibatkan golongan-golongan yang berada dalam kategori fakir dan miskin. Ibrahim (1998) mengatakan bahwa Islam memberikan rasa keseimbangan dan meletakkan dasar bagi keadilan yang merata. Islam mendorong tumbuhnya lembaga-lembaga sosial untuk saling menolong di masa-masa sulit. Salah satu lembaga yang penting adalah lembaga pengelolaan zakat dalam rangka membantu mereka yang membutuhkan.

Lembaga pengelola zakat merupakan lembaga non-profit yang bertujuan untuk membantu umat Islam menyalurkan zakat, infaq dan sedekah kepada yang berhak. Aktivitas tersebut melibatkan beberapa pihak yang saling berkait yakni pemberi zakat, pengelola, dan penerima zakat. Pada beberapa kasus, pengelola dana bukan orang-orang atau institusi yang benarbenar dikenal oleh pemberi dana. Hal ini, seperti lembaga publik lainnya, memunculkan kebutuhan adanya akuntabilitas. Pemberi zakat menginginkan akuntabilitas pengelola terhadap integritas, efisiensi dan efektivitas dana yang mereka serahkan.

Dengan disahkannya Undang-Undang Nomer 23 Tahun 2011 Tentang Pengelolaan Zakat yang menggantikan UndangUndang Nomer 38 Tahun 1999, diharapkan dapat memberikan kepastian dan tanggung jawab baru kepada pemerintah dalam mengelola badan amil zakat (BAZNAS, BAZNAZ propinsi, BAZNAS kabupaten/kota) dan mampu mengkoordinasikan kepentingan stakeholders.

Menurut Undang-Undang Zakat, pengelolaan zakat bertujuan: 
1. meningkatkan efektivitas dan efisiensi pelayanan dalam pengelolaan zakat; dan

2. meningkatkan manfaat zakat untuk mewujudkan kesejahteraan masyarakat dan penanggulangan kemiskinan.

Untuk melaksanakan pengelolaan zakat, pemerintah membentuk BAZNAS. BAZNAS berkedudukan di ibu kota negara. BAZNAS merupakan lembaga pemerintah nonstruktural yang bersifat mandiri dan bertanggung jawab kepada Presiden melalui Menteri. BAZNAS merupakan lembaga yang berwenang melakukan tugas pengelolaan zakat secara nasional. Lingkup kewenangan pengumpulan zakat oleh BAZNAS, BAZNAS provinsi, dan BAZNAS kabupaten/kota diatur dalam Peraturan Pemerintah.

Menurut Arafat (2013) lembaga zakat yang sampai sekarang ini dihimpun telah tercatat sebanyak 1 BAZNAS (Badan Amil Zakat nasional) di tingkat nasional, 33 BAZNAS provinsi dan 240 BAZNAS kabupaten/kota serta 18 LAZ (lembaga Amil Zakat) tingkat nasional yang sudah mendapat pengukuhan dari Menteri Agama.

Arafat menerangkan bahwa jumlah mustahik (orang yang wajib menerima zakat) di seluruh Indonesia adalah 33.943.313 jiwa. Dari segi gender nyaris berimbang: 49,9 persen mustahik adalah laki-laki, sisanya 50,1 persen perempuan. Lalu, 52 persen mustahik belum menikah; 42 persen menikah; cerai mati 4,6 persen; dan cerai hidup 1,4 persen. Tingkat pendidikan mereka pun sangat rendah, yakni 77 persen tidak tamat/tamat SD. Sebagian besar mustahik bekerja di sektor pertanian $(63,1$ persen); industri 8,9; perdagangan 8,8; dan jasa 7.2. Sementara peta kemiskinan juga mancatat terdapat 23.676.263 muzakki di seluruh Indonesia dengan jumlah kumulatif terbesar di Jawa Barat 4.721.101 orang, Jawa Timur 2.871.741 orang, DKI Jakarta 2.467.677 orang, Jawa Tengah 2.181.139, Banten 1.324.908 orang, dan Sumatra Utara 1.094 .889 orang. Sebagian besar (60,6 persen) 


\section{Nur Hisamuddin}

muzakki adalah laki-laki; tetapi potensi perempuan tidak bisa diabaikan, yakni 39,4 persen. Para muzakki ini sebagian besar berusia antara 25-59 tahun (26,1 persen berusia antara 25-34 tahun; 25.00 antara 35-44; dan 26,4 persen antara 45-59 tahun). Latar belakang pekerjaan para muzakki: 27,3 persen bekerja pada sektor pertanian; 20,8 persen pada sektor industri; 18,2 persen pada sektor jasa; dan 10,7 persen di sektor industri. Dengan adanya data di atas betapa banyak jumlah mustahik yang ada di seluruh wilayah Indonesia, dimana mereka sangat membutuhkan dana tersebut untuk memenuhi kebutuhan hidup sehari-hari. Meski demikian fakta yang ada menunjukkan hal yang berbeda.

Transparansi pelaporan menjadi sesuatu yang urgen. Transparansi bertujuan untuk memberikan kepercayaan antar pihak-pihak yang berkepentingan dalam lembaga. Transparansi dapat dilakukan dengan penyajian laporan keuangan yang wajar. Kewajaran mengacu pada kesesuaian penyusunan laporan keuangan yang berdasarkan pada Prinsip Akuntansi Berterima Umum (PABU).

Dalam artikel ini akan dibahas mengenai bagaimana seharusnya laporan keuangan lembaga zakat disusun dan prinsip apa yang seharusnya dipakai dalam penyusunan laporan keuangan. Diharapkan studi ini dapat memberi gambaran bagi berbagai pihak khususnya lembaga zakat agar transparansi lembaga zakat dapat dijalankan.

\section{Pembahasan}

\section{Organisasi pengelola zakat, infaq dan sedekah}

Menurut Undang-Undang Republik Indonesia Nomor 23 tahun 2011 tentang Pengelolaan Zakat dijelaskan bahwa menunaikan zakat merupakan kewajiban bagi umat Islam yang mampu sesuai dengan syariat Islam. Zakat merupakan pranata keagamaan yang bertujuan untuk meningkatkan keadilan dan kesejahteraan masyarakat. Dalam rangka meningkatkan daya 
guna dan hasil guna, zakat harus dikelola secara melembaga sesuai dengan syariat Islam.

Pengelolaan zakat adalah kegiatan perencanaan, pelaksanaan, dan pengkoordinasian dalam pengumpulan, pendistribusian, dan pendayagunaan zakat. Zakat adalah harta yang wajib dikeluarkan oleh seorang muslim atau badan usaha untuk diberikan kepada yang berhak menerimanya sesuai dengan syariat Islam. Infak adalah harta yang dikeluarkan oleh seseorang atau badan usaha di luar zakat untuk kemaslahatan umum. Sedekah adalah harta atau non-harta yang dikeluarkan oleh seseorang atau badan usaha di luar zakat untuk kemaslahatan umum. Muzaki adalah seorang muslim atau badan usaha yang berkewajiban menunaikan zakat. Mustahik adalah orang yang berhak menerima zakat. Badan Amil Zakat Nasional yang selanjutnya disebut BAZNAS adalah lembaga yang melakukan pengelolaan zakat secara nasional. Lembaga Amil Zakat yang selanjutnya disingkat LAZ adalah lembaga yang dibentuk masyarakat yang memiliki tugas membantu pengumpulan, pendistribusian, dan pendayagunaan zakat. Unit Pengumpul Zakat yang selanjutnya disingkat UPZ adalah satuan organisasi yang dibentuk oleh BAZNAS untuk membantu pengumpulan zakat.

\section{Pengumpulan, distribusi dan pendayagunaaan zakat}

Ismail (2009) memberikan pedoman tentang pola pengumpulan, distribusi dan pendayagunaan zakat sebagai berikut:

a. Pola pengumpulan zakat

Pemerintah tidak melakukan pengumpulan zakat. Melainkan hanya berfungsi sebagai motivator, regulator, dan fasilitator dalam pegumpulan zakat. Pengumpulan zakat dilakukan oleh badan amil zakat yang dibentuk oleh pemerintah dan lembaga amil zakat yang dibentuk oleh masyarakat dan 


\section{Nur Hisamuddin}

dikukuhkan oleh pemerintah. Pengumpulan zakat dapat dilakukan melalui penyerahan langsung (datang) ke Badan Amil Zakat melalui conter zakat, unit pengumpulan zakat, pos, bank, pemotongan gaji, dan pembayaran zakat yang dapat mengurangi penghasilan kena pajak.

b. Pola pendistribusian zakat

Pola pendiatribusian zakat adalah bentuk penyaluran dana zakat dari muzzaki kepada mustahik dengan melalui amil. Penyaluran zakat dapat dibedakan menjadi dua bentuk, yakni bantuan sesaat (pola tradisonal atau konsumtif) dan pemberdayaan (pola kontemporer atau produktif). Pola tradisional yaitu penyaluran batuan dana zakat diberikan langsung kepada mustahik. Pola kontemporer atau produktif (bantuan pemberdayaan) adalah pola penyaluran dana zakat kepada mustahik yang ada dipinjamkan oleh amil untuk kepentingan aktifitas suatu usaha (bisnis).

c. Pola pendayagunaan zakat

Pola pendayagunaan zakat adalah cara (system) distribusi dan alokasi dana zakat berdasarkan dengn tuntunan perkembangan zaman dan sesuai dengan cita dan rasa syariat, pesan dan kesan ajaran Islam. Sasaran pendayagunaan zakat, Allah SWT menetapkan delapan golongan mustahik (Asnaf Mustahik). Terdiri dari fakir, miskin, amil, muallaf, riqab, gharimin, fi sabilillah, dan ibnu sabil. Klasifikasi golongan mustahik dapat dibagi dalam dua kelompok besar, yaitu: kelompok permanen dan kelompok temporer. Kelompok permanen terdiri dari fakir, miskin, amil, dan muallaf. Empat golongan mustahik ini diasumsikan akan selalu ada di wilayah kerja organisasi pengelolaan zakat dan karena itu penyaluran dana kepada mereka akan terus menerus atau dalam waktu lama walaupun secara individu penerima berganti-ganti. Kelompok temporer: riqab, gharimin, fi sabilillah dan ibnu sabil. Empat 
golongan mustahik kini diasumsikan tidak selalu ada di wilayah kerja suatu organisasi pengelolaan zakat.

\section{Kualitas manajemen}

Kualitas manajemen suatu lembaga pengelola zakat harus dapat diukur. Untuk itu, ada tiga kata kunci yang dapat dijadikan sebagai alat ukurnya (Dompet Dhuafa, 2011). Pertama, amanah. Sifat amanah merupakan syarat mutlak yang harus dimiliki oleh setiap amil zakat. Tanpa adanya sifat ini, hancurlah semua sitem yang dibangun. Kedua, sikap profesional. Sifat amanah belumlah cukup. Harus diimbangi dengan profesionalitas pengelolaannya. Ketiga, transparan. Dengan transparannya pengelolaan zakat, maka kita menciptakan suatu sistem kontrol yang baik, karena tidak hanya melibatkan pihak intern organisasi saja, tetapi juga akan melibatkan pihak eksternal. Dan dengan transparansi inilah rasa curiga dan ketidakpercayaan masyarakat akan dapat diminimalisasi.

Ketiga kata kunci ini dapat diimplementasikan apabila didukung oleh penerapan prinsip-prinsip operasionalnya, yaitu; pertama, kita harus melihat aspek kelembagaan. Dari aspek kelembagaan, pengumpul zakat seharusnya memperhatikan berbagai faktor, yaitu: visi dan misi, kedudukan dan sifat lembaga, legalitas dan struktur organisasi, aliansi strategis.

Kedua, aspek sumber daya manusia (SDM). SDM merupakan aset yang paling berharga. Sehingga pemilihan siapa yang akan menjadi amil zakat harus dilakukan dengan hatihati. Untuk itu perlu diperhatikan faktor perubahan paradigma bahwa amil zakat adalah sebuah profesi dengan kualifikasi SDM yang khusus.

Ketiga, aspek sistem pengelolaan. Pengumpul zakat harus memiliki sistem pengelolaan yang baik, unsur-unsur yang harus diperhatikan adalah lembaga tersebut harus memiliki sistem, prosedur dan aturan yang jelas, manajemen yang terbuka, mempunyai activity plan, mempunyai lending commite, memiliki 


\section{Nur Hisamuddin}

sistem akuntansi dan manajemen keuangan, diaudit, publikasi, dan perbaikan secara berkala.

Kualitas manajemen suatu lembaga pengelola zakat harus terus menerus di perbaiki dengan cara meningkatkan manajemen yang amanah, profesional dan transparan. Sifat amanah merupakan syarat mutlak yang harus dimiliki oleh setiap organisasi zakat. Manajemen yang amanah harus diimbangi dengan profesionalitas pengelolaannya. Dan dengan transparannya pengelolaan zakat, maka dapat menciptakan suatu sistem kontrol yang baik, karena tidak hanya melibatkan pihak intern organisasi saja, tetapi juga akan melibatkan pihak eksternal. Dan dengan transparansi inilah rasa curiga dan ketidakpercayaan masyarakat akan dapat diminimalisasi.

Ketiga kunci manajemen OPZ yang amanah, professional dan transparan dapat dicapai dengan ditunjang dengan pelaporan keuangan yang baik. Pelaporan keuangan dikatakan baik ketika laporan keuangan yang disusun lengkap, benar dan sesuai dengan ketentuan standar akuntansi yang berlaku yaitu pernyataan standar akuntansi keuangan (PSAK) Syariah 109 yang telah disyahkan bulan April 2011 sebagai pedoman bagi para penyusun laporan keuangan organisasi pengelola zakat (OPZ).

\section{Laporan keuangan organisasi pengelola zakat}

Menurut pernyataan standar akuntansi keuangan (PSAK) syariah 109 jenis-jenis laporan keuangan utama yang harus disusun oleh sebuah organisasi pengelola zakat (OPZ); Pertama, neraca merupakan suatu laporan keuangan yang menggambarkan posisi keuangan atau kekayaan suatu organisasi pengelola zakat pada saat tertentu. Tujuan disusunnya laporan ini adalah untuk menyediakan informasi mengenai aktiva, kewajiban, dan saldo dana dan informasi mengenai hubungan diantara unsurunsur tersebut pada waktu tertentu. Sedangkan kegunaan dari neraca adalah untuk: menilai kemampuan organisasi pengelola zakat untuk memberikan jasa secara berkelanjutan dan menilai 
likuiditas, fleksibilitas keuangan, kemampuan untuk memenuhi kewajibannya, dan kebutuhan pendanaan eksternal.

Kedua, laporan sumber dan penggunaan dana, merupakan suatu laporan yang menggambarkan kinerja organisasi, yang meliputi penerimaan dan penggunaan dana pada suatu periode tertentu. Laporan ini disusun dengan tujuan untuk menyediakan informasi mengenai: pengaruh transaksi dan peristiwa lain yang mengubah jumlah dan sifat saldo dana, hubungan antar transaksi dan peristiwa lainnya dan bagaimana penggunaan sumber daya dalam pelaksanaan berbagai program. Laporan sumber dan penggunaan dana ini berguna untuk mengevaluasi kinerja dalam suatu periode, menilai upaya, kemampuan, dan kesinambungan organisasi dalam memberikan jasanya dan menilai pelaksanaan tanggung jawab dan kinerja pengelola.

Ketiga, laporan arus kas, merupakan suatu laporan yang menggambarkan arus kas masuk dan arus kas keluar pada suatu periode tertentu. Tujuan disusunnya laporan ini adalah untuk menyajikan informasi mengenai penerimaan dan pengeluaran kas organisasi pada suatu periode tertentu.

Keempat, laporan dana termanfaatkan merupakan laporan perubahan dana termanfaatkan dibuat mengakomodasi transaksi pengeluaran atau penerimaan neraca yang harus dilaporkan dalam laporan sumber dan penggunaan dana.

Kelima, catatan atas laporan keuangan merupakan rincian atau penjelasan detail dari laporan keuangan sebelumnya. Rincian tersebut dapat bersifat kuantitatif maupun kualitatif. Catatan atas laporan keuangan memuat hal-hal berikut: informasi umum mengenai lembaga, kebijakan akuntansi yang digunakan dalam penyusunan laporan keuangan, penjelasan dari setiap akun yang dianggap memerlukan rincian lebih lanjut dan kejadian setelah tanggal neraca. 


\section{Akuntabilitas}

Akuntabilitas merupakan salah satu prinsip utama tata kelola organisasi yang mengisyaratkan adanya perwujudan kewajiban seseorang atau unit organisasi untuk mempertanggungjawabkan pengelolaan dan pengendalian sumber daya dan pelaksanaan kebijakan yang dipercayakan kepadanya dalam rangka pencapaian tujuan yang telah ditetapkan melalui media pertanggungjawaban secara periodik (Saragi, 2012).

Megawati (2012) menjelaskan bahwa Public Interest Research and Advocacy Center (PIRAC) dan Humanitarian Forum Indonesia (HFI) Badan Nasional Penanggulan Bencana, FOZ (Forum Zakat) dan organisasil lainnya menyusun pedoman akuntabilitas sejumlah 13 (tiga belas) prinsip dan penjelasannya yang digunakan untuk menjelaskan hal-hal terkait akuntabilitas pengelolaan bantuan kemanusiaan. Ke-13 (tiga belas) prinsipprinsip tersebut adalah:

Independensi, bahwa organisasi adalah otonom dan bebas dari pengaruh dan kepentingan-kepentingan pemerintah, partai politik, donor/lembaga penyandang dana, sektor bisnis dan siapapun yang dapat menghilangkan independensi organisasi dalam bertindak bagi kepentingan umum.

Komitmen Organisasi, bahwa organisasi memiliki perangkat kebijakan yang jelas dan tegas terkait kualitas dan akuntabilitas untuk dapat diterapkan dalam pengelolaan bantuan kemanusiaan.

Kompetensi, bahwa organisasi memiliki dan mengembangkan kapasitas yang relevan dalam pengelolaan bantuan kemanusiaan sesuai standar bantuan kemanusiaan.

Non-Diskriminasi, bahwa organisasi pengelola bantuan selalu menerapkan asas tidak membedakan orang menurut jenis kelamin, suku, agama, ras, dan aliran politik. 
Partisipasi, bahwa organisasi melibatkan pemangku kepentingan terkait dan penerima manfaat dalam semua tahapan pengelolaan bantuan.

Transparansi, bahwa organisasi menyediakan informasi yang jelas dan benar serta dapat dipertanggungjawabkan terkait dengan pengelolaan bantuan kemanusiaan.

Koordinasi, bahwa organisasi berkomunikasi dengan pemangku kepentingan dan organisasi pengelola bantuan kemanusiaan lainnya melalui wadah koordinasi yang ada dalam pengelolaan bantuan kemanusiaan.

Pembelajaran dan Perbaikan, bahwa setiap pengalaman yang pernah dialami dalam pengelolaan bantuan kemanusiaan menjadi bahan pembelajaran untuk perbaikan.

Kemitraan, bahwa kerjasama pengelolaan bantuan kemanusiaan dilakukan dengan asas kesetaraan.

Non-Proselitis, bahwa organisasi tidak melakukan upaya penyebarluasan agama, keyakinan, paham, dan ideologi politik melalui distribusi bantuan kemanusiaan.

Mekanisme Umpan Balik, bahwa organisasi memiliki mekanisme untuk menerima saran, kritik dan tanggapan dari pemangku kepentingan untuk peningkatan dan perbaikan pengelolaan bantuan.

Kemandirian, bahwa organisasi mampu melakukan upaya-upaya mobilisasi sumber daya dan distribusi bantuan kemanusiaan yang tidak menimbulkan ketergantungan.

Keberpihakan Terhadap Kelompok Rentan, bahwa organisasi memiliki keberpihakan yang jelas kepada kelompok rentan (ibu hamil, ibu menyusui, anak-anak, lansia, difabel atau penyandang cacat, pengidap HIV AIDS, minoritas seks, di setiap tahapan dan dampak pengelolaan bantuan kemanusiaan

\section{Akuntansi zakat, infaq dan sedekah (PSAK 109)}

Tujuan, Pernyataan ini bertujuan untuk mengatur pengakuan, pengukuran, penyajian dan pengungkapan transaksi 


\section{Nur Hisamuddin}

zakat dan infaq/sedekah.

Ruang lingkup, PSAK ini berlaku untuk amil yang menerima dan menyalurkan zakat dan infaq/sedekah. Amil yang menerima dan menyalurkan zakat dan infaq/sedekah, yang selanjutnya disebut "amil", merupakan diberikan organisasi pengelola zakat yang pembentukannya dimaksudkan untuk mengumplkan dan menyalurkan zakat dan infaq/sedekah.

PSAK ini tidak berlaku untuk entitas syariah yang menerima dan menyalurkan zakat dan infaq/sedekah, tetapi bukan kegiatan utamanya. Entitas tersebut mengacu PSAK 101: Penyajian Laporan Keuangan Keuangan Syariah.

\section{Definisi-definisi khusus;}

1. Amil adalah entitas pengelola zakat yang pembentukannya dan atau pengukuhannya diatur berdasarkan peraturan perundang-undangan yang dimaksudkan untuk mengumpulkan dan menyalurkan zakat dan infaq/ sedekah.

2. Dana amil adalah bagian amil atas dana zakat dan infaq/ sedekah serta dana lain yang oleh pemberi diperuntukkan bagi amil. Dana amil digunakan untuk pengelolaan amil.

3. Dana infaq/sedekah adalah bagian nonamil atas penerimaan infaq/sedekah.

4. Dana zakat adalah bagian nonamil atas penerimaan zakat.

5. Infaq/sedekah adalah harta yang diberikan secara sukarela oleh pemiliknya, baik yang peruntukannya dibatasi (ditentukan) maupun tidak dibatasi.

6. Mustahiq adalah orang atau entitas yang berhak menerima zakat.

7. Muzakki adalah individu muslim yang secara syariah wajib membayar (menunaikan) zakat.

8. Nisab adalah batas minimum harta yang wajib dikeluarkan zakatnya. 
9. Zakat adalah harta yang wajib dikeluarkan oleh muzakki sesuai dengan ketentuan syariah untuk diberikan kepada yang berhak menerimanya (mustahik).

Karakteristik, Zakat merupakan kewajiban syariah yang harus diserahkan oleh muzakki kepada mustahiq baik melalui amil mupun secara langsung. Ketentuan zakat mengatur mengenai persyaratan nisab, haul (baik yang peiodik maupun tidak periodik) tarif zakat (qadar), dan peruntukannya.

Infaq sedekah merupakan donasi sukarela, baik ditentukan maupun tidak ditentukan peruntukannya oleh pemberi infaq/ sedekah.

Zakat dan infaq/sedekah yang diterima oleh amil harus dikelola sesuai dengan prinsip-prinsip syariah dan tata kelola yang baik.

\section{Pengakuan dan pengukuran zakat;}

1. Pengakuan Awal

Penerimaan zakat diakui pada saat kas atau aset lainnya diterima, sedangkan zakat yang diterima dari muzakki diakui sebagai penambah dana zakat:

a. Jika dalam bentuk kas maka sebesar jumlah yang diterima.

b. Jika dalam bentuk non kas maka sebesar nilai wajar aset non kas tersebut.

Penentuan nilai wajar aset nonkas yang diterima menggunakan harga pasar. Jika harga pasar tidak tersedia, maka dapat menggunakan metode penentuan nilai wajar lainnya sesuai dengan PSAK yang relevan.

Zakat yang diterima diakui sebagai dana amil untuk bagian amil dan dana zakat untuk bagian nonamil.

Penentuan jumlah atau persentase bagian untuk masingmasing mustahiq ditentukan oleh amil sesuai dengan prinsip 


\section{Nur Hisamuddin}

syariah dan kebijakan amil. Jika muzakki menentukan mustahiq yang harus menerima penyaluran zakat melalui amil maka aset zakat yang diterima seluruhnya diakui sebagai dana zakat. Jika atas jasa tersebut amil mendapatkan ujrah/fee maka diakui sebagai penambah dana amil.

2. Pengukuran setalah pengakuan awal

Jika terjadi penurunan nilai aset zakat nonkas, jumlah kerugian yang ditanggung harus diperlakukan sebagai pengurang dana zakat atas pengurang dana amil tergantung dari sebab terjadinya kerugian tersebut.

Penurunan nilai aset zakat diakui sebagai:

a) Pengurang dana zakat, jika terjadi tidak disebabkan oleh kelalaian amil.

b) Kerugian dan pengurang dana amil, jika disebabkan oleh kelalaian amil.

3. Penyalur Zakat

Zakat yang disalurkan kepada mustahiq diakui sebagai pengurang dana zakat sebesar:

a) Jumlah yang diserahkan, jika dalam bentuk kas.

b) Jumlah tercatat, jika dalam bentuk aset nonkas.

\section{Pengakuan dan Pengukuran Infaq/Sedekah}

Penerimaan infaq/Sedekah

Infaq/Sedekah yang diterima diakui sebagai dana infaq/ sedekah terikat atau tidak terikat sesuai dengan tujuan pemberi infaq/sedekah sebesar:

a) Jumlah yang diterima, jika dalam bentuk kas

b) Nilai wajar, jika dalam bentuk nonkas

Penentuan nilai wajar aset nonkas yang diterima menggunakan harga pasar untuk aset nonkas tersebut. Jika pasar tidak tersedia maka dapat menggunakan metode penentuan nilai wajar lainnya sesuai yang diatur dalam PSAK yang relevan. 
Infaq/Sedekah yang diterima diakui sebagai dana amil untuk bagian amil dan dana infaq/sedekah untuk bagian penerima infaq/sedekah. Penentuan jumlah atau persentase bagian untuk para penerima infaq/sedekah ditentukan oleh amil sesuai dengan prinsip syariah dan kebijakan amil.

Infaq/Sedekah yang diterima dapat berupa kas atau aset nonkas. Aset nonkas dapat berupa aset lancar atau tidak lancar. Aset tidak lancar yang diterima oleh amil dan diamanahkan untuk dikelola dinilai sebesar nilai wajar saat penerimaannya dan diakui sebagai aset tidak lancar infaq/sedekah. Penyusutan dari aset tersebut diperlakukan sebagai pengurang dana infaq/sedekah terikat apabila penggunaan atau pengelolaan aset tersebut sudah ditentukan oleh pemberi.

Amil dapat pula menerima aset nonkas yang dimaksudkan oleh pemberi untuk segera disalurkan. Aset seperti ini diakui sebagai aset lancar. Aset ini dapat berupa bahan habis pakai, seperti bahan makanan, atau aset yang memiliki umur ekonomis panjang, seperti mobil ambulance. Aset nonkas lancar dinilai sebesar nilai perolehan sedangkan aset nonkas tidak lancar dinilai sebesar nilai wajar sesuai dengan PSAK yang relevan. Penurunan nilai aset infaq/sedekah tidak lancar diakui sebagai:

a) Pengurang dan infaq/sedekah, jika terjadi bukan disebabkan oleh kelalaian amil

b) Kerugian dan pengurang dana amil, jika disebabkan oleh kelalaian amil.

\section{Penerimaan infaq/sedekah non kas}

Dalam hal amil menerima infaq/sedekah dalam bentuk aset (nonkas) tidak lancar yang dikelola oleh amil, maka aset tersebut harus dinilai sesuai dengan PSAK yang relevan.

Dana infaq/sedekah sebelum disalurkan dapat dikelola dalam jangka waktu sementara untuk mendapatkan hasil yang optimal. Hasil dana pengelolaan diakui sebagai penambah dana infaq/shoodaqoh. 


\section{Penyaluran infaq/sedekah}

Penyaluran dana infaq/sedekah diakui sebagai pengurang dan infaq/sedekah sebesar:

a. Jumlah yang diserahkan, jika dalam bentuk kas.

b. Nilai tercatat aset yang diserahkan, jika dalam bentuk nonkas.

Penyaluran infaq/sedekah kepada amil lain merupakan penyaluran yang mengurangi dana infaq/sedekah sepanjang amil tidak akan menerima kembali aset infaq/sedekah yang disalurkan tersebut. Penyaluran infaq/sedekah kepada penerima akhir dalam skema dana bergulir dicatat sebagai piutang infaq/ sedekah bergulir dan tidak mengurangi dana infaq/sedekah.

\section{Pengakuan dan Pengukuran Dana Non Halal}

Penerimaan dana non halal adalah semua penerimaan dari kegiatan yang tidak sesuai dengan prinsip syariah, antara lain penerimaan jasa giro atau bunga dari bank konvensional. Penerimaan dana non halal pada umunya terjadi dalam kondisi darurat atau kondisi yang tidak diinginkan oleh entitas syariah karena secara prinsip dilarang.

Penerimaan dana non halal diakui sebagai dana non halal, yang terpisah dari dana zakat, dana infaq/shodaoqh dan dana amil. Aset non halal disalurkan sesuai dengan syariah.

\section{Penyajian dan Pengungkapan Zakat dan Infaq/Sedekah}

Amil menyajikan dana zakat, dana infaq/sedekah, dana amil, dan dana non halal secara terpisah dalam Laporan Posisi Keuangan (Neraca)

\section{Zakat}

Amil harus mengungkapkan hal-hal berikut terkait dengan traksaksi zakat, tetapi tidak terbatas pada:

a) Kebijakan penyaluran zakat, seperti penerimaan skala prioritas penyaluran dan penerimaan. 
b) Kebijakan pembagian antara dana amil dan dana nonamil atas penerimaan zakat, seperti persentase pembagian, alasan dan konsistensi kebijakan.

c) Metode penentuan nilai wajar yang digunakan untuk penerimaan zakat berupa aset nonkas.

d) Rincian jumlah penyaluran dana zakat yang mencakup jumah beban pengelolaan dan jumlah dana yang diterima langsung mustahiq, dan

e) Hubungan istimewa antara amil dan mustahiq yang meliputi:

1. Sifat hubungan istimewa

2. Jumlah dan jenis aset yang disalurkan, dan

3. Persentase dari aset yang disalurkan tersebut dari total penyaluran selama periode

\section{Infaq/Sedekah}

Amil harus mengungkapkan hal-hal berikut terkait dengan transaksi infaq/sedekah, tetapi tidak terbatas pada:

a) Metode penetuan nilai wajar yang digunakan untuk penerimaan infaq/sedekah berupa aset nonkas.

b) Kebijakan pembagian antara dana amil dan dana nonamil atas penerimaan infaq/sedekah, seperti persentase pembagian, alasan dan konsistensi kebijakan.

c) Kebijakan penyaluran infaq/sedekah, seperti penentuan skala proritas penyaluran dan penerima.

d) Keberadaan dana infaq/sedekah yang tidak langsung disalurkan tetapi dikelola terlebih dahulu, jika ada, maka harus diungkapkan jumlah dan persentase dari sejumlah penerimaan infaq/sedekah selama periode pelaporan serta alasannya.

e) Hasil yang diperoleh dari pengelolaan yang dimaksud di hurf (d) diungkapkan secara terpisah. 
f) Penggunaan dana infaq/sedekah menjadi aset kelolaan yang diperuntukkan bagi yang berhak, jika ada, jumlah dan persentase terhadap seluruh penggunaan dana infaq/sedekah serta alasannya.

g) Rincian jumlah penyaluran dana infaq/sedekah yang mencakup jumlah beban pengelolaan dan jumlah dana yang diterima langsung oleh penerima infaq/sedekah.

h) Rincian dana infaq/sedekah berdasarkan peruntukannya, terikat dan tidak terikat, dan hubungan istimewa antara amil dengan penerima infaq/sedekah yang meliputi:

1. Sifat hubungan istimewa

2. Jumlah dan jenis aset yang disalurkan, dan

3. Persentase dari aset yang disalurkan tersebut dari total penyaluran selama periode

Selain membuat pengungkapan tersebut diatas, amil mengungkapkan hal-hal berikut:

a) Keberadaan dana nonhalal, jika ada diungkapkan mengenai kebijakan atas penerimaan dan penyaluran dana, alasan, dan jumlahnya, dan

b) Kinerja amil atas penerimaan dan penyaluran dana zakat dan dana infaq/sedekah.

\section{Komponen Laporan Keuangan}

Komponen laporan keuangan yang lengkap dari amil terdiri dari:

1. Laporan Posisi Keuangan (Neraca)

2. Laporan Perubahan Dana

3. Laporan Perubahan Aset Kelolaan

4. Laporan Arus Kas

5. Catatan atas Laporan Keuangan 


\section{Simpulan}

Berdasarkan kajian dan pemaparan yang telah disajikan di atas maka dapat diambil kesimpulan bahwa dengan terbitnya Undang Undang lembaga zakat, lembaga zakat kini memiliki peran penting dalam pengelolaan zakat karenanya membutuhkan manajemen yang berkualitas. Adanya cabang hampir di semua daerah di seluruh Indonesia, membuat perputaran uang yang besar dan membutuhkan pengelolaan keuangan yang baik.

Laporan keuangan merupakan cerminan dari pengelolaan keuangan. Penyusunannya harus didasarkan pada prinsip yang diterima umum agar dapat dipahami sehingga kandungan informasinya dapat digunakan oleh pihak-pihak yang berkepentingan. Di Indonesia dasar penyusunannya menggunakan PSAK 109 yang terdiri dari Neraca, Laporan Perubahan Dana, Laporan Perubahan Aset Kelolaan, Laporan Arus Kas dan Catatan atas Laporan Keuangan. Untuk menjaga kepercayaan publik, laporan keuangan yang diterbitkan nantinya harus teraudit.

\section{Daftar Pustaka}

Afifi Fauzi Abbas, Zakat Untuk Kesejahteraan Bersama. LAZISMU Situbondo, 2011.

Anwar Ibrahim, Renaisans Asia: Gelombang Reformasi Di Ambang Alaf Baru. Mizan, Jakarta, 1998.

Ikatan Akuntan Indonesia (IAI). Standar Akuntansi Keuangan. Salemba Empat, Jakarta, 2009.

Iwan Triyuwono, dan Roekhudin, Konsistensi Praktik Sistem Pengendalian Intern dan Akuntabilitas Pada Lazis, Studi Kasus di Laziz X Jakarta. Proceeding SNA II, Malang, 1999. 
J. Clark, Democratizing Development: The Role of Voluntary Organizations. Kumarian Press, West Hartford, CT, 1991.

J. Cutt, and Murray, V, Accountability and Effectiveness Evaluation in Non-Profit Organizations, Routledge, London, 2000.

M. Abdul Mannan, Teori dan Praktek Ekonomi Islam, PT Dana Bhakti Wakaf, Yogyakarta, 1993.

Masdar F. Mau'udi, Agama Keadilan: Risalah Zakat (Pajak) dalam Islam, Pustaka Firdaus, Jakarta, 1991.

Multifiah, Pengaruh Zakat, Infak, Shadaqah (ZIS) terhadap Kesejahteraan Rumah Tangga Miskin, Jurnal-Jurnal ilmu Sosial .Fakultas Ekonomi Universitas Brawijaya Malang, 2009.

Nugraha Winoto, Pengaruh Dana Zakat Produktif Terhadap Keuntungan Usaha Mustahiq Penerima Zakat (Studi Kasus BAZ Kota Semarang) Fakultas Ekonomi Universitas Diponegoro Semarang, 2011.

Taufik Abdullah, Zakat Collection and Distribution in Indonesia. The Islamic Voluntary Sector in Southeast Asia. Institute of Southeast Asian Studies, Singapore, 1991.

Undang-Undang Republik Indonesia Nomor 23 Tahun 2011 Tentang Pengelolaan Zakat 